\title{
Reassessment of conservation status of the Senecio trapezuntinus Boiss. (Asteraceae)
}

\author{
Salih Terzioğlu a,*, Kamil Coşkunçelebi ${ }^{\text {b }}$
}

\begin{abstract}
Senecio trapezuntinus Boiss. has hitherto been known from type locality (A7: Trabzon - Ortahisar). It was assessed under the VU and CR because of location number and habitat quality. With the two newly recorded populations (A8 Trabzon Çaykara and A7: Gümüşhane - Kürtün) apart from type locality, the total known population number reaches to four for this local endemic. According to increasing location number, extent of occurrence calculated to be $1671 \mathrm{~km}^{2}$ (less than $5000 \mathrm{~km}^{2}$ ), an area of occupancy calculated to be $16 \mathrm{~km}^{2}$ (less than $500 \mathrm{~km}^{2}$ ) we updated the threat category as EN B1ab(i,ii,iii,iv)+2ab(ii,iii,iv) in the present study.
\end{abstract}

Keywords: Endemic, IUCN, Senecio, Turkey

\section{Senecio trapezuntinus Boiss. (Asteraceae)'un koruma statüsünün yeniden değerlendirilmesi}

\begin{abstract}
Özet: Senecio trapezuntinus Boiss. türü şimdiye kadar sadece tip yeri olan A7: Trabzon - Ortahisar'dan bilinmektedir. Bu tür, lokasyon sayısı ve şehirleşme gibi nedenlere bağlı olarak daha önce VU ve CR tehlike kategorilerinde değerlendirilmiştir. Tip yeri dışında, A8 Trabzon - Çaykara ve A7: Gümüşhane - Kürtün'den yeni saptanan iki popülasyon ile bu lokal endemiğin lokasyon sayısı dört olmuştur. Bu bulgulara dayalı olarak türün yayılış alanı $1671 \mathrm{~km}^{2}\left(5000 \mathrm{~km}^{2}\right.$ den az), yaşam alanı ise $16 \mathrm{~km}^{2}$ $\left(500 \mathrm{~km}^{2}\right.$ den az) olarak hesapland. Bu çalışmayla türün tehlike kategorisi EN B1ab(i,ii,iii,iv)+2ab(ii,iii,iv) olarak güncellendi. Anahtar kelimeler: Endemik, IUCN, Senecio, Türkiye
\end{abstract}

\section{Introduction}

The assessment or reassessment of conservation status of vascular plant taxa is crucial in biodiversity conservation (Kahraman et al., 2012; Ekim et al., 2013; Trias-Blasi et al., 2017). Turkey, with nearly 12000 vascular plant taxa, $32 \%$ of which are endemics, is one of the richest center in the world (Güner et al., 2012) and we are responsible for this natural heritage in terms of plant protection. Endemic plants, many of which at high risk of global extinction, are the most known of these taxa and require strict conservation treats. According to Turkish Red Data Boook (Ekim et al., 2000), the number of endemic plant taxa under the EX, CR, EN and VU are 13, 181, 843, 1457 respectively. Senecio trapezuntinus Boiss. is a distinctive plant by its ovate, cordate basal leaves, glabrescent and with a conspicuous tertiary venation and cauline leaves lyrate to ovate usually amplexicaul-auriculate. It was described by Boissier (1875) based on Balansae specimen from Trabzon ("in rupibus ad lapidicinae prope Trapezuntem Ponti") and lectotypified by Calvo (2013) based on Bourgeau 127 (G photo!). This local endemic has been assessed by Ekim et al. (2000) under the VU however later it was assessed as CR: B2 by Hamzaoğlu et al. (2009) and as CR: B2ab(ii, iii) by Ekim et al. (2013). The type locality is under the influence of urbanization and also detrimental anthropogenic effects such as to be grown lettuce, cabbage and parsley. The World Conservation Union aims to classify the taxa at the risk of global extinction (IUCN, 2012). In addition to the classification of threatened species, the red list categories provide for the determination of threat factors as well as appropriate plans for the protection process. Especially in forest ecosystems today, forest management plans should better handle these taxa in planning process. In the process of preparing management plans for forest ecosystems in particular, it is imperative that these taxa and their distribution in the forest be identified and mapped by using up-to-date technologies. The forest functions to be identified and the recommended protective practices are different for the taxa in the different categories.

With the present study we aim to reassess the threat category based on updated chorological data of $S$. trapezuntinus endemic to Turkey.

\section{Material and methods}

Samples of $S$. trapezuntinus were collected from A7 Trabzon- Ortahisar, Esentepe area (type place) in 2007, 77 m (KATO: 7897); A8 Trabzon- Çaykara, Taşkıran Village in 2007, $490 \mathrm{~m}$ (KATO: 7868) and Çaykara, Karaçam Village in 2009, $750 \mathrm{~m}$ (Hamzaoğlu, 5430) and, A7 Gümüşhane- Kürtün, Süme stream in 2010, $1148 \mathrm{~m}$

\footnotetext{
$凶 \quad$ a Karadeniz Technical University, Faculty of Forestry, Department of Forest Botany, 61080, Trabzon, Turkey

b Karadeniz Technical University, Faculty of Science, Department of Biology, 61080, Trabzon, Turkey

@ * Corresponding author (İletişim yazarı): sterzi@ktu.edu.tr

$\checkmark \quad$ Received (Geliş tarihi): 01.02.2018, Accepted (Kabul tarihi): 14.03.2018
}

Citation (Atıf): Terzioğlu, S., Coşkunçelebi, K., 2018. Reassessment of conservation status of the Senecio trapezuntinus Boiss. (Asteraceae). Turkish Journal of Forestry, 19(2): 109-112. DOI: $\underline{10.18182 / \text { tjf.388405 }}$ 
(KATO: 8763). All coordinates were determined by using Global Positioning System (GPS) in their habitat by the present authors excepting one coordinate of Karaçam Village (Trabzon) obtained from Hamzaoğlu et al. (2009) which is close to Taşkıran population. Threat category has been assessed according to red list criteria of IUCN (2012) using data of Area of occupancy $\left(\mathrm{AOO}, \mathrm{km}^{2}\right)$, Extent of occurrence $\left(\mathrm{EOO}, \mathrm{km}^{2}\right)$, population numbers and field observations. Distribution map, calculation of the EOO and AOO was carried out by using Geo-Cat (Bachman et al., 2011).

\section{Result and discussion}

The new chorological records of $S$. trapezuntinus (Figure 1) highlighted that it is not very rare taxa as it was reported by Matthews (1975), Ekim et al. (2000) and Hamzaoğlu et al. (2009).

Matthews (1975) reported that $S$. trapezuntinus is an Euxine element and all reported populations are fell into Euro-Siberian phytogeographic region of Turkey (Davis, 1975) as seen in Figure 2. From point of geographical scale of organization, the IUCN criteria is for global species assessment and not for regional, national or local levels (IUCN, 2012). These criteria here applied for $S$. tarpezuntinus at global level. As seen in the Figure 2, its distribution was restricted to Northeastern Anatolia. The
EOO calculated according to 4 locations is $1671 \mathrm{~km}^{2}$ and AOO is $16 \mathrm{~km}^{2}$. The threatened category was assessed as EN according to EOO and AOO (IUCN, 2012). The distribution area is moderately under the press of urbanization, home gardening, road and hydroelectric power construction. Thus this species was re-assessed under the Endangered (EN)B1ab(ii,iii,iv)+2ab(ii,iii,iv) category according to red list criteria of IUCN (2012).

Protecting endangered plants both in forest and other ecosystems is a crucial task for countries. Biodiversity integrated forest management plans are the important tools for this task and this plans need many data of indicator species most amount of which is under extinction risk according to IUCN. Assessment of conservation status is the first step of developing conservation strategy for a species (Fenu et al., 2011). After determining extinction risk of threatened taxa, conservation status of them needs to be identified. As well, this makes a significant contribution to the feasibility for possible protection measures to be taken in the process of forest management plan. All taxa in threatened categories, CR, EN and VU, require different forestry implementations. Habitat of the taxon at $\mathrm{CR}$ category for example, should be designated as core area. This area surrounded by buffer zone where the objectives should be focused on biodiversity conservation, not wood production. That is why, conservation status assessment at global level is extremely important.



Figure 1. a,b-Type locality; c- Home garden on the edge of type locality; d,e-Radiate capitula; f-Inflorescence; g-Cauline leaf 




Figure 2. Distribution map showing extend of occurrence of Senecio trapezuntinus Boiss.

Though their importance in terms of protection, the taxa at EN category do not require such strict protection measures, but may be subject to special forest techniques; such as moderate silvicultural practices. Moreover, the status of these taxa need to be updated by using data, if found, from newly identified populations. It is reported that the accepted standard for doing this is the categories and criteria of the IUCN Red List of Threatened Species (IUCN, 2012; Fenu et al., 2011), and start with Critically Endangered taxa of IUCN is initial. S. trapezuntinus is classified into the EN threat category after discovering previously unknown localities. This category is subject to more moderate applications than the CR category requiring the most intensive protection measures.

Depending on discovering new locations, it was revealed that the distribution of the plant varied between 77 $\mathrm{m}$ and $1148 \mathrm{~m}$ asl. which is a contribution to ecology of the studied taxon. The vegetation community of the type place is pseudomacchie vegetation dominated by native shrubs and naturalized Robinia pseudoacacia L. while the other populations' are natural forest dominated by Picea orientalis (L.) Link and Fagus orientalis Lipsky.

This species is under different threats in its different habitats. Especially in edge of type place, local people try to grow some vegetables by destroying the habitat where the slope is not appropriate for the agricultural activities. Other populations are under the threat of road and hydroelectric power plant construction. Necessary precautions, as seen below, should be taken in order to lessen the effects of threats to populations of the species;

- From point of in-situ conservation, the populations should be considered in determining the forest functions through the process of preparing biodiversity integrated forest management plans,

- Routes of newly constructed roads should be modified within the technical possibilities,
- Individuals under water of hydroelectric power plant should be transported to other neighboring habitats which have the similar ecological conditions,

- Local people should avoid agricultural practices along the edge of the type place, and the adjacent vegetable gardens should be rehabilitated to natural conditions,

- Detailed studies should be conducted to determine the possible new populations and monitoring of existing populations,

- Diaspores of this species should be sent to botanical gardens for ex-situ conservation.

\section{Acknowledgement}

We want to express our special thanks to İsa Bozkır for his helping during the preparing map.

\section{References}

Bachman, S., Moat, J., Hill, A.W., De la Torre J., Scott B., 2011. Supporting Red List threat assessments with GeoCAT: Geospatial conservation assessment tool. ZooKeys, 150, 117-126.

Boissier, P.E., 1875. Flora Orientalis. Vol. 3, H. Georg, Genève, Basel \& Lyon.

Calvo, J., 2013. Systematics of Senecio sect. Crociseris (Compositae, Senecioneae). PhD thessis, Escuela Technica Superior de Ingenieros de Montes Universidad Politechnica de Madrid, Spain.

Davis, P.H., 1975. Flora of Turkey and the East Aegean Islands. Vol. 1, Edinburgh University Press, Edinburgh.

Ekim, T., Koyuncu, M., Vural, M., Duman, H., Aytaç, Z., Adigüzel, N., 2000. Red Data Book of Turkish Plants (Pteridophyta and Spermatophyta). Turkish Association for the Conservation of Nature and Van Centinental University, Ankara. 
Ekim, T., Terzioğlu, S., Eminağaoğlu, Ö., Coşkunçelebi, K., 2013. Turkey. In: Solomon, J., Shulkina, T. and Schatz, G.E., (Ed.), Red List of the Endemic Plants of the Caucasus. Missouri Botanical Garden Press, Saint Louis, pp. 209-241.

Fenu, G., Mattana, E., Bacchetta, G., 2011. Distribution, status and conservation of a Critically Endangered, extremely narrow endemic: Lamyropsis microcephala (Asteraceae) in Sardinia. Oryx, 45(2): 180-186.

Güner, A., Aslan, S., Ekim, T., Vural, M., Babaç, M.T., 2012. Türkiye Bitkileri Listesi (Damarlı Bitkiler). Nezahat Gökyiğit Botanik Bahçesi ve Flora Araştırmaları Derneği Yayını, İstanbul.

Hamzaoğlu, E., Aksoy, A., Budak, U., 2009. Türkiye Senecio L. (Asteraceae) Türlerinin Taksonomik Revizyonu, TÜBİTAK (106T240).
IUCN, 2012. Guidelines for application of IUCN red list criteria at regional and national levels: ver. 4.0. - IUCN Species Survival Commission.

Kahraman, A., Bagherpour, S., Karabacak, E., Doğan, M., Doğan, H.M., Uysal, İ., Celep, F., 2012. Reassessment of conservation status of the genus Salvia (Lamiaceae) in Turkey II. Turkish Journal of Botany, 36, 103-124.

Matthews, V.A., 1975. Senecio L. In: Davis, P.H. Flora of Turkey and the East Aegean Islands, vol.: 5. Edinburgh University Press, Edinburgh.

Trias-Blasi, A., Gücel, S., Özden, Ö., 2017.Current distribution and conservation status reassessment of the Cyprus Tulip (Tulipa cypria: Liliaceae), new data from Northern Cyprus. Plant Biosystems, 151(3): 394-402. 